\title{
PENGARUH VARIASI PH TERHADAP KEMAMPUAN BAKTERI DALAM DEKOLORISASI LIMBAH CAIR GULA RAFINASI
}

\section{THE EFFECT OF PH VARIATION ON DECOLORIZATION ABILITY OF BACTERIA ON REFINED SUGAR WASTE WATER}

\author{
Lailatus Sa'diyah*, Kinanti Ayu Puji Lestari \\ Program Studi DIII Farmasi, Akademi Farmasi Surabaya, Jawa Timur, Indonesia \\ *Email: 1ailatuss@akfarsurabaya.ac.id
}

Diterima: 25 Januari 2019. Disetujui: 29 Februari 2019. Dipublikasikan: 31 Maret 2019

\begin{abstract}
Abstrak: Penelitian ini bertujuan untuk mengetahui kemampuan bakteri indigenus dalam mendekolorisasi limbah cair gula rafinasi dalam berbagai pH.Penelitian ini merupakan penelitian experimental dengan rancangan acak lengkap dengan 3 kali pengulangan. Data yang diperoleh dari penelitian ini berupa: 1) jumlah bakteri indigenus pendekolorisasi limbah; 2) pengukuran nilai dekolorisasi; 3) nilai Log TPC; 4) identifikasi tiga bakteri dengan nilai dekolorisasi tertinggi. Hasil isolasi dan uji dekolorisasi menunjukkan bahwa terdapat sembilan bakteri indigenus yang mampu mendekolorisasi zat warna melanoidin. Sembilan bakteri indigenus tersebut yang memiliki kemampuan dekolorisasi terbaik secara berturut-turut yaitu DC2, DC4 dan DC1 dengan nilai dekolorisasi masing

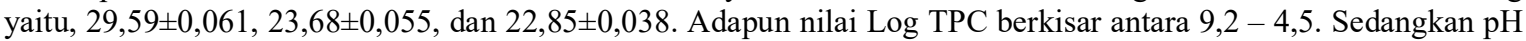
terbaik untuk dekolorisasi ketiga bakteri tersebut adalah 11. Hasil identifikasi menunjukkan bahwa ketiga bakteri terbaik tersebut adalah Bacillus sp dan Pseudomona diminuta. Berdasarkan hasil tersebut dapat disimpulkan bahwa untuk menguraikan melanoidin atau dekolorisasi limbah cair gula rafinasi dapat menggunakan bakteri indigenus yg bias diisolasi dari limbah itu sendiri.
\end{abstract}

Kata Kunci: Biodegradasi, Dekolorisasi, Melanoidin, Gula rafinasi, Bacillus sp, dan Pseudomonas diminuta

Abstract: This aim of this study is to know indigenous bacteria ability and it's in decoloring refined sugar waste wateronvarious $\mathrm{pH}$ level. Thisresearch is experimental study with three replications. Data obtained from this study were: 1) The number of potential indigenous bacteria in decoloring waste water isolated from the waste water; 2) the measurement of decolorization absorbance; 3) the number of Log TPC; 4)Bacterial Identification of three highest decoloring ability. The study showed that there are nine potential bacteria in decoloring refined sugar waste water. The three highest decoloring bacteria are DC2, DC4, and DC1 with decoloring result simultaneously are $29,59 \pm 0,061,23,68 \pm 0,055$, dan 22,85 $\pm 0,038$. The Log TPC number resulted are between 9.2 to 4.5 . The three decoloring bacteria above were best decolored the refined sugar waste on $\mathrm{pH}$ level eleven. While the three decoloring bacteria identified as Pseudomonas diminuta (DC1) and Bacillus sp (DC2 and DC4). In conclusion, indigenous bacteria can be used to degradated melanoidin on refined sugar waste water.

Keywords: Biodegradation, decolorization, melanoidin, refined sugar, Bacillus sp, and Pseudomonas diminuta

\section{PENDAHULUAN}

Limbah gula rafinasi adalah limbah berwarna coklat gelapyang berasal dari pembuangan pabrik gula rafinasi yang pada umumnya memiliki bau tidak sedap, $\mathrm{pH}$ rendah, salinitas tinggi, kadar COD dan BOD tinggi pula. Warna coklat gelap pada limbah disebabkan oleh polimer warna yang disebut melanoidin [1]. Struktur warna limbah tersebutdapat mengganggu keseimbangan lingkungan jika dibuang di lingkungan sekitarnya [1] pembuangan limbah mengandung melanoidin ke lingkungan akan berdampak buruk bagi lingkungan yaitu dapat mengurangi panetrasi sinar matahari ke sungai, danau atau pesisir pantai dan menurunkan aktivitas fotosintesis dan oksigen terlarut yang kemudian dapat membahayakan kehidupan air.Limbah yang mengandung melanoidin merupakan sumber utama polusi air dan tanah karena tidak larut dalam air dan resisten terhadap mikroba, sehingga proses biologi konvensional seperti perlakuan pemberian sludge tidaklah cukup [4]. Oleh karena itu, limbah cair industri pabrik gula rafinasi ini memerlukan perlakuan awal sebelum dibuang ke lingkungan $[6,8]$

Salah satu upaya yang dapat dilakukan untuk mengolah limbah adalah biodegradasi. Secara umum biodegradasi atau penguraian bahan (senyawa) organik oleh mikroorganisme dapat terjadi bila terjadi transformasi struktur sehingga terjadi perubahan integritas molekuler [5].Tujuan dari penelitian ini adalah untuk mendapatkan bakteri indigenus yang memiliki potensi dalam mendekolorisasi limbah gula rafinasi dalam berbagai kondisi $\mathrm{pH}$.

\section{METODEPENELITIAN}

Penelitian ini dilakukan di Laboratorium Mikrobiologi UNAIR pada tahun 2015-2016. Penelitian menggunakan Rancangan Acak Lengkap 
(RAL) pola faktorial $3 \times 3$ dengan diulang tiga kali. Faktor pertama adalah $\mathrm{pH}(9,11$, dan 13) dan faktor kedua adalah Log TPC. Variabel yang diamati adalah penurunan warna limbah (dekolorisasi). Nilai penurunan dekolorisasi kemudian diuji statistika ANOVA One way. Adapun tahapan penelitian ini adalah:

\section{Isolasi bakteri indigenus}

Limbah cair gula rafinasi diambil sebanyak $1 \mathrm{~mL}$ kemudian di encerkan ke dalam $9 \mathrm{~mL}$ larutan fisiologis steril sebagai pengenceran $10^{-1}$. Pengenceran dilakukan hingga pengenceran $10^{-5}$. Kemudian, sebanyak $1 \mathrm{~mL}$ dari masing-masing tiga pengenceran terakhir dimasukkan ke dalam cawan petri lalu media NA dituang secukupnya ke dalam cawan petri. Proses pengenceran dan pembiakan bakteri dilakukan secara aseptis. Biakan bakeri diinkubasi selama 24 jam.

\section{Skrining bakteri pendekolorisasi}

Bakteri yang telah diisolasi dan dimurnikan diuji kemampuan dalam mendekolorisasi limbah gula rafinasi dengan cara sebanyak satu hingga dua ose biakan diambil dan dimasukkan ke dalam $20 \mathrm{~mL}$ media NB secara aseptis lalu inkubasi selama semalam hingga mencapai OD 1. Sebanyak $10 \%(5 \mathrm{~mL})$ biakkan dimasukkan kedalam 45 $\mathrm{mL}$ limbah. Lalu diinkubasi selama 24 jam dalam suhu ruangan. Hal yang sama dilakukan pada limbah yang dikondisikan menjadi $\mathrm{pH} 11$ dan 9.

\section{Tahap perlakuan variasi $\mathbf{p H}$}

Sebanyak $240 \mathrm{~mL}$ limbah dibagi menjadi 3 (menjadi $80 \mathrm{~mL}$ ) dan dikondisikan pHnya menjadi $\mathrm{pH}$ 9, 11, dan $\mathrm{pH}$ asli limbah (13). Persiapan limbah dilakukan secara aseptis. 80 $\mathrm{mL}$ limbah dengan variasi $\mathrm{pH}$ dibagi dan dimasukkan ke dalam empat botol untuk empat bakteri terpilih. Sebanyak 10\% masing-masing inokulum bakteri terpilih dari media NB dimasukkan ke dalam botol yang telah berisi limbah dengan $\mathrm{pH}$ yang bervariasi. Perlakuan tiap bakteri dilakukan pengulngan sebanyak tiga kali. Inkubasi limbah dalam suhu $30^{\circ} \mathrm{C}$ selama 48 jam

\section{Absorbsi UV-Vis}

Absorbsi UV-Vis diukur dengan menggunakan spektrofotometer (Shimadzu UV-160) pada kisaran panjang gelombang 400$480 \mathrm{~nm}$.

\section{Tahap Identifikasi Bakteri}

Empat bakteri terpilih yang murni diamati morfologi makoskopis koloni, mikroskopis sel, gram negatif atau positif, dan diuji oksidase menggunakan oksidase strip dan peroksidase, kemudian diuji menggunakan Microbact

\begin{abstract}
Identification Kits (Microbact ${ }^{\mathrm{TM}}$ GNB 12A dan 12B).Identifikasi bakteri dilakukan menggunakan buku Bergey's Manual of Determinative Bacteriology [2].
\end{abstract}

\section{HASIL DAN PEMBAHASAN}

Dari hasil isolasi dan skrining bakteri indigenus pada limbah cair pabrik gula rafinasi di Cilegon Jawa Barat, didapatkan sembilan jenis bakteri yang mampu mendekolorisasi warna limbah. Kesembilan bakteri tersebut adalah dc1, dc2, dc3, dc4, dc5, dc6, dc7, dc8 dan dc9. Kemampuan dekolorisasi bakteri dalam keadaan normal limbah (pH 13) dan suhu $30^{\circ} \mathrm{C}$ ditunjukkan pada persen dekolorisasi kesembilan bakteri dan angka Total Plate Count pada (table 1). Hal tersebut sesuai denganhasil penelitian yang menyatakan bahwa limbah gula rafinasi mengandung bakteri indigenus yang berperan dalam dekolorisasi limbah cair gula rafinasi [10]

Tabel 1. Persentase dekolorisasi hasil skrining bakteri dan nilai Log TPC.

\begin{tabular}{llc}
\hline Bakteri & \multicolumn{1}{c}{ \% dekolorisasi } & $\begin{array}{c}\log \\
\text { cfu/mL }\end{array}$ \\
\hline DC1 & $15,94 \pm 0,041$ & 4,50 \\
DC2 & $6,34 \pm 0,021$ & 4,08 \\
DC3 & $14,60 \pm 0,051$ & 4,32 \\
DC4 & $15,94 \pm 0,059$ & 4,47 \\
DC5 & $7,04 \pm 0,050$ & 4,23 \\
DC6 & $3,97 \pm 0,028$ & 3,98 \\
DC7 & $6,73 \pm 0,048$ & 4,33 \\
DC8 & $2,30 \pm 0,027$ & 3,92 \\
DC9 & $7,40 \pm 0,022$ & 4,29 \\
\hline
\end{tabular}

Tabel 2. Persentase dekolorisasi pada $\mathrm{pH} 11$ dan 9

\begin{tabular}{ccc}
\hline Bakteri & \multicolumn{2}{c}{ \% Dekolorisasi } \\
\cline { 2 - 3 } & \multicolumn{1}{c}{$\mathrm{pH} \mathrm{9}$} & \multicolumn{1}{c}{$\mathrm{pH} \mathrm{11}$} \\
\hline DC1 & $3,22 \pm 0,017$ & $22,85 \pm 0,038$ \\
DC2 & $5,64 \pm 0,025$ & $29,59 \pm 0,061$ \\
DC3 & $4,23 \pm 0,010$ & $22,30 \pm 0,064$ \\
DC4 & $3,56 \pm 0,056$ & $23,68 \pm 0,055$ \\
DC5 & $0,43 \pm 0,004$ & $29 \pm 0,18$ \\
DC6 & $3,34 \pm 0,039$ & $15,47 \pm 0,045$ \\
DC7 & $2,35 \pm 0,020$ & $14,74 \pm 0,026$ \\
DC8 & $1,10 \pm 0,028$ & $9,54 \pm 0,040$ \\
DC9 & $5,74 \pm 0,012$ & $8,53 \pm 0,067$ \\
\hline
\end{tabular}

Berdasarkan (tabel 2), sembilan bakteri yang didapatkan memiliki kemampuan yang berbeda-beda dalam mendekolorisasi. Kemampuan berbeda, beda bakteri dalam dekolorisasi dipengaruhi oleh banyak faktor, seperti $\mathrm{pH}$, suhu, lama inkubasi, dan sumber karbon dan nitrogen. Faktor-faktor yang mempengaruhi dekolorisasi sangat berperan penting dalam aktivitas enzimatis bakteri dalam menguraikan senyawa limbah hingga terjadi penurunan warna. 
Jika dilihat dalam tabel, bakteri dc2 memiliki kemampuan tertinggi dalam dekolorisasi yaitu $29,59 \%$ pada $\mathrm{pH} 11$. Diikuti oleh bakteri dc4 dengan kemampuan dekolorisasi hingga 23,68\% dalam $\mathrm{pH}$ 11 pula. Pada nilai TPC yang didapatkan juga menunjukkan nilai tertinggi pertumbuhan bakteri yaitupada bakteri DC4 yaitu sebesar $4,47 \mathrm{cfu} / \mathrm{ml}$ kemudian dc2 yaitu 4,02. Nilai dekolorisasi dan pertumbuhan bakteri yang selarasa dan sama besarnya meyakinkan akan kemampuan bakteri indigenus tersebut dalam mendekolorisasi limbah cair gula rafinasi. Kemampuan bakteri tumbuh dan mampu mendekolorisasi pada $\mathrm{pH} 11$ menunjukkan bahwa bakteri tersebut spesifik optimum dalam mendekolorisasi pada $\mathrm{pH} 11$ dan tumbuh baik pada pH 11 pula.
Tabel 3. Nilai Log TPC bakteri pendekolorisasi limbah cair gula rafinasi

\begin{tabular}{ccc}
\hline Bakteri & $\mathrm{pH} \mathrm{9}$ & $\mathrm{pH} \mathrm{11}$ \\
\cline { 2 - 3 } & $\begin{array}{c}\text { Log } \\
\mathrm{cfu} / \mathrm{mL}\end{array}$ & $\begin{array}{c}\text { log } \\
\mathrm{cfu} / \mathrm{mL}\end{array}$ \\
\hline DC1 & 4,30 & 4,71 \\
DC2 & 4,50 & 4,79 \\
DC3 & 4,39 & 4,58 \\
DC4 & 4,37 & 4,65 \\
DC5 & 3,97 & 4,72 \\
DC6 & 4,32 & 4,51 \\
DC7 & 4,16 & 4,43 \\
DC8 & 4,26 & 4,45 \\
DC9 & 4,46 & 4,10 \\
\hline
\end{tabular}

Tabel 4. Hasil identifikasi isolate pendekolorisasi limbah cair gula rafinasi

\begin{tabular}{llll}
\hline \multirow{2}{*}{ Klasifikasi } & \multicolumn{3}{c}{ Nama Isolat } \\
\cline { 2 - 4 } & \multicolumn{1}{c}{ DC1 } & \multicolumn{1}{c}{ DC2 } & \multicolumn{1}{c}{ DC4 } \\
\hline Filum & Proteobacteria & Firmicutes & Firmicutes \\
Kelas & Gamma Proteobacteria & Bacilli & Bacilli \\
Ordo & Pseudomonadales & Bacillales & Bacillales \\
Family & Pseudomonadaceae & Bacillaceae & Bacillaceae \\
Genus & Pseudomonas & Bacillus & Bacillus \\
Spesies & Pseudomonas diminuta & Bacillus sp & Bacillus sp \\
\hline
\end{tabular}

Berdasarkan uji statistik yang dilakukan, terdapat pengaruh variasi $\mathrm{pH}$ terhadap nilai dekolorisasi dengan nilai signifikansi yaitu $0,000(\alpha$ $<0,05)$. $\mathrm{pH}$ berpengaruh secara langsung terhadap aktivitas enzimatis bakteri dalam mendekolorisasi zat warna limbah. Namun, aktivitas enzimatis selama dekolorisasi tiap bakteri berbeda-beda [11].

Kemampuan bakteri dalam mendekolorisasi dalam berbagai kondisi $\mathrm{pH}$ basa menunjukkan bahwa dalam dekolorisasi zat warna terutama melanoidin, tidak hanya dapat dilakukan oleh bakteri dengan kemampuan dekolorisasi pada $\mathrm{pH}$ asam seperti yang telah banyak ditemukan. Namun juga ditemukan bakteri indigenus limbah basa yang mampu mendekolorisasi dalam $\mathrm{pH}$ basa pula. Hal ini berlawanan dengan penelitian Screening of differentfungi for decolorization of molassesyang menyatakan bahwa dekolorisasi secara efisien akan terjadi jika lingkungan asam ( $\mathrm{pH} 3-7)$ [12]. Sehingga perlu diketahui bahwa beberapa bakteri dapat melakukan dekolorisasi dalam $\mathrm{pH}$ tertentu. Hal ini dikarenakan oleh daya hidup bakteri yang spesifik pada lingkungan tertentu [11]. Oleh karena itu pada bakteri yang diisolasi dari lingkungan basa ini menghasilkan persentase dekolorisasi yang rendah pada $\mathrm{pH}$ sembilan, dikarenakan kemampuan bakteri yang tahan terhadap suasana basa ( $\mathrm{pH} 11$-13).

Kemampuan dekolorisasi melanoidin yang dilakukan oleh bakteri ditengarai karena bakteri memiliki enzim dekolirisasi melanoidin yaitu lignin peroksidase, manganese peroksidase dan lakase [6].Adapun uji identifikasi yang telah dilakukan menunjukkan bahwa tiga bakteri yang memiliki kemampuan dekolorisasi tertinggi secara berturut yaitu dc2, dc4 dan dc1 adalah bakteri Bacillus sp (dc2 dan dc4) dan Pseudomonas diminuta (dc1). Bakteri Bacillus sp dan pseudomonas sp merupakan bakteri yang memiliki kemampuan biodegradasi [4].

\section{KESIMPULAN}

Berdasarkan hasil penelitian dan pembahasan dapat di simpulkan bahwa:

1. Bakteri indigenus yang didapatkan dari limbah cair pabrik gula rafinasi memiliki potensi dalam mendekolorisasi limbah tersebut

2. Bakteri indigenus pendekolorisasi limbah cair gula rafinasi bekerja maksimal pada $\mathrm{pH}$ basa yaitu 11. Begitu juga dengan pertumbuhan bakteri baik pada $\mathrm{pH}$ tersebut.

3. Tiga bakteri indigenus dengan kemampuan dekolorisasi tertinggi adalah Pseudomonas diminuta (DC1) and Bacillus sp (DC2 and DC4).

\section{DAFTAR PUSTAKA}

[1]. Naik, N. M., Jagadeesh, K. S., \& Alagawadi, A. R. (2008). Microbial decolorization of spentwash: a review. Indian Journal of Microbiology, 48(1), 41-48.

[2]. Garrity, G. (2007). Bergey's Manual ${ }^{\circledR}$ of Systematic Bacteriology: Volume 2: The Proteobacteria, Part B: The Gammaproteobacteria (Vol. 2). Springer Science \& Business Media.

[3]. Chandra, R., Bharagava, R. N., \& Rai, V. (2008). Melanoidins as major colourant in 
sugarcane molasses based distillery effluent and its degradation. Bioresource Technology, 99(11), 4648-4660.

[4]. Evershed, R. P., Bland, H. A., van Bergen, P. F., Carter, J. F., Horton, M. C., \& RowleyConwy, P. A. (1997). Volatile compounds in archaeological plant remains and the Maillard reaction during decay of organic matter. Science, 278(5337), 432-433.

[5]. Handrianto prasetyo. (2018). Mikroorganisme pendegradasi TPH (Total Petroleum Hydrocarbon) sebagai agen bioremediasi tanah tercemar minyak bumi : Review. Jurnal Sains Health, 2

[6]. Kumar, P., \& Chandra, R. (2006). Decolourisation and detoxification of synthetic molasses melanoidins by individual and mixed cultures of Bacillus spp. Bioresource Technology,97(16), 20962102.

[7]. Lestari K., 2016. Aktivitas Enzim Bakteri Potensial Yang Berperan Dalam Dekolorisasi Limbah Cair Pabrik Gula Rafinasi. http://repository.unair.ac.id/id/eprint/29118

[8]. Mohana, S., Desai C., Madamwar D., (2007). Biodegradation anddecolourisation of anaerobically treated distillery spent wash by anovel bacterial consortium. Bioresource Technology. 98, 333-339

[9]. Pazouki, M., J. Shayegan dan A. Afshari, (2008). Screening of microorganisms for decolorizationof treated distillery wastewater. Iran. Journal Science Technology. 32: 53-60.

[10]. Sa'diyah Lailatus. (2016). Isolasi bakteri indigenus limbah cair pabrik gula rafinasi dan potensinya dalam dekolorisasi melanoidin. http://repository.unair.ac.id/id/eprint/29109

[11]. Tiwari Soni, Rajeeva Gaur, Priyanka Rai dan Ashutosh Tripathi. (2012). Decolorization of Distillery Effluent by Thermotolerant Bacillus subtilis. American Journal of Applied Sciences 9 (6): 798-806.

[12]. Seyis, I. and T. Subasing, (2009). Screening of differentfungi for decolorization of molasses. BrazilianJ. Microbiol., 40: 61-65. 